\title{
Accompaniment needs of nursing students related to the dying patient
}

\author{
D Van Rooyen, D Cur \\ Professor of Nursing, Nelson Mandela Metropolitan University
}

R Laing, M Cur

Professional Nurse, Australia

WJ Kotzé, D Cur

Emeritus Professor of Nursing, Nelson Mandela Metropolitan University

\section{Keywords:}

Accompaniment, nursing students, death, dying patient, clinical learning environment

\section{Sleutelwoorde: Begeleiding,} studentverpleegkundiges, dood, sterwende pasiente, kliniese leeromgewing

\section{Correspondence address:}

Dr Dalena van Rooyen

Nursing Science Department

PO Box 77000

Nelson Mandela Metropolitan University PORT ELIZABETH

6031

Tel : (041) 504-2960

Fax : (041) 504-2616

E-mail : dalena.vanrooven@nmmu.ac.za

\section{Abstract: Curationis 28(4): $31-39$}

Nurse educators are responsible for accompanying students towards becoming capable, competent professional nurses who are a credit to themselves, their patients, colleagues and profession. Student nurses need, therefore, to be taught to render comprehensive nursing care to patients in all stages of their lives, including when they are dying. Being confronted with human suffering and death is challenging and traumatic. Those exposed to such events on a daily basis need to have a solid foundation of self preservation to see past the pain of suffering and to bring light and hope to those in need. A young student nurse will only experience positive growth and development in these circumstances if she is also cared for and guided with understanding. The researcher utilized a qualitative, explorative, descriptive and contextual design based on the phenomenological approach to enquiry. The following question was asked at the beginning of each unstructured phenomenological interview: "How was if for you to care for a dying or deceased patient?" The central theme identified that student nurses experience turmoil in their different relationships in their accompaniment of the dying patient. Guidelines based on the central theme and sub-themes that emerged from raw data, as well as literature, are offered as strategies to promote/enhance optimal accompaniment of student nurses caring for the dying patient.

\section{Opsomming}

Dosente in verpleegkunde is verantwoordelik om bekwame professionele verpleegkundes op te lewer wat ' $n$ aanwins vir hulself, hul pasiente, kollegas en die beroep sal wees. Om menslike lyding en die dood in die gesig te staar is beide ' $n$ uitdagende en traumatiese aangeleentheid. Diegene wat op ' $n$ daaglikse basis aan hierdie situasies blootgestel word, het ' $n$ stewige grondslag van volharding nodig om verby die pyn en Iyding te kyk en 'n lig van hoop aan diegene in nood, te bring. 'n Jong verpleegkundige sal hierdie insig slegs verkry indien sy versorg en met begrip gelei word. Die navorser het ' $n$ kwalitatiewe, verkennende, beskrywende en kontekstuele benadering gevolg, gebaseer op die fenomenologiese benadering tot die studie. Die volgende vraag is by die aanvangs van elke ongestruktureerde fenomenologiese onderhoud gestel: Hoe het jy dit enaar om In sterwende of afgestorwe pasient te versorg? Die sentrale tema wat geïdentifiseer is, is dat studentverpleegkundiges verwarring in hul verskillende verhoudings ervaar terwyl hulle die sterwende pasiënt begelei. Riglyne gebaseer op die sentrale tema en subtemas wat vanuit sowel die onverwerkte data en Iiteratuur voortspruit, word aangebied as strategieë om studentverpleegkundiges wat sterwende pasiente versorg, optimaal te begelei. 


\section{Introduction}

Death is a universal and individually unique event of the human experience. In today's social climate, death is viewed as something to be avoided at all costs. Medicine with its technological advances pursues immortality. These scientific advances do not change the fact that death is a part of every human existence. Dying was once considered to be a normal part of the life cycle. Today it is often considered to be a medical problem that should be handled by health care providers. Technological advances in medicine have caused the care of those who are dying to become depersonalised and mechanical (DeLaune and Ladner, 2002:424).

Nurses are looked upon to humanise the care of the dying. Nurses spend more time with patients who are facing the end of life than any other member of the health care team and, therefore, play an important role in the initial stages of bereavement - the grief experienced with the loss of a significant other. Bereavement is a universal normal response to a loss, draining on a person both emotionally and physically.

Each patient has to do his own dying we cannot do it for him. Each dying patient is unique and there is no ultimate guide for health care professionals (Luthert and Robinson, 1993:90). A person's imminent death creates conflicts and tensions in those caring for him. The nurse's individual reactions to death inevitably affect his/her ability to give optimum care to a dying patient and his family. Exploring these reactions is essential to the nurse's professional growth and development (Jacobi in Earle, Argondizzo and Kutscher, 1976:2). Kiger (1994:680) states that, on entering their first clinical allocation, student nurses expect to experience difficulty with the emotional care of dying patients and dealing with the pain of seeing them suffer and the shock of seeing a dead body. Concern is expressed as to how they will communicate with relatives, what to say or how to tell them that their loved one has died.

In South Africa, one faces death frequently due to the increased incidence of violence and terminal illness. For example, according to the UNAIDS/ World Health Organisation annual report, “AIDS epidemic update 2003", Auto Immune Deficiency Disease Syndrome
(AIDS) claimed an estimated 3 million lives in 2003. Moreover, an estimated 5 million people acquired the human immunodeficiency virus (HIV) in 2003 bringing the estimated number of people globally living with the virus to 40 million (UNAIDS, 2003). Closer to home, the Eastern Cape Department of Health reported the Eastern Cape Province to have an estimated $534251 \mathrm{HIV}$ positive individuals, a prevalence of 8,3 percent (Zuzile, 2003:19).

Nursing students are faced with challenging new experiences, such as caring for the dying patient, from the beginning of their training and, consequently, need a considerable degree of guidance and support.

\section{Problem statement and research questions}

The researcher, while accompanying second year students in the clinical nursing environment, heard a student verbalise "It's just a case of the unknown, I think you just have to get used to it." Student nurses have mentioned difficulties in communicating meaningfully with the dying patient, as well as not knowing what to say to the patient's family after the patient has died.

Student nurses appear to avoid coping with dying patients by becoming tough, cynical and uncaring. The researcher, in his first year as a student nurse, experienced the death of a patient while giving a bed-bath. The next occasion the researcher was in the ward, a second patient died during a bed-bath. Although this was not the researcher's first exposure to death, it resulted in tremendous anxiety regarding bedbathing patients and gave rise to questions such as "What did I do wrong?"

This led the researcher to formulate the following research questions:

- How do nursing students experience the accompaniment of the dying patient and care of the patient after death?

- What guidelines can be proposed to assist clinical mentors/ward staff in their accompaniment of student nurses in the clinical nursing environment related to the experience of accompanying the dying patient and care of the patient after death?

\section{Research objectives}

The objectives of the study were to:

- Explore and describe how nursing students experience the accompaniment of the dying patient and care of the patient after death.

- Develop guidelines for clinical mentors/ward staff to provide optimal accompaniment of student nurses in the clinical nursing environment related to the experience of accompanying the dying patient and care of the patient after death.

\section{Terminology}

For the purpose of the study the following concepts are defined:

\section{Clinical Learning Environment}

The clinical learning environment is the environment in which students participate in actual observation and treatment of patients, providing physical, psychological, spiritual and social support to patients in order to promote and maintain safe, effective patient care (adapted by researcher based on reviewed literature and from Blackwell, 1994:150).

\section{Student Nurse}

For the purpose of this study, a student nurse is an individual enrolled for the first two years of the four-year Baccalaureus Curationis programme. Throughout this study reference to the personal pronoun 'her' and 'she' will include both genders.

\section{Accompaniment}

A planned and deliberate intervention by the clinical mentor, including all those activities that occur in a purposeful fashion according to the identified needs of the student, to facilitate development of self-reliance and independence (Kotzè, 1998:10).

\section{Death}

For the purpose of this study, death will be considered as having occurred in one of the three ways described by Hector and Whitfield (1982:10). The patient may die quite suddenly, sometimes with no previous symptoms. The patient may die from a fatal disease, like advanced cancer, where it is possible to note the signs of approaching death and to forecast the likely time of death. Thirdly, the patient may be placed on a life-support machine 
following an accident or sudden emergency and the criterion of brain death is invoked to decide if death has occurred.

\section{The Dying Patient}

Within this study, the dying patient will refer to the period where the nurse cares for the patient up until the time the patient dies, as well as the period after death until the deceased patient has been removed from the nurse's care.

\section{Research design and method}

The following discussion focuses on the research design and research method utilized in this study.

\section{Research Design}

The research study followed a qualitative, explorative, descriptive and contextual design based on a phenomenological approach to inquiry, reflecting the experiences of student nurses related to the accompaniment of the dying patient and care of the patient after death.

\section{Research Method}

The collection of data and the analysis of data were implemented and divided into two phases.

\section{Phase 1}

Unstructured phenomenological interviews were conducted with second year nursing students whilst exposed to the clinical learning environment. Purposive sampling was used and data were collected by means of a combination of unstructured phenomenological interviews, personal journals kept by participants and the researcher's field notes. Data were analysed according to the descriptive analysis method of Tesch (1990 cited in Creswell, 2003: 192).

\section{Phase 2}

Once the data had been interpreted, guidelines were developed for the clinical mentors and ward staff to provide optimal accompaniment for student nurses in the clinical environment. These guidelines should assist clinical mentors and all staff members working with student nurses in making the experience of death less threatening.
The research population for this study comprised 59 second year nursing students who were all registered as students at the University of Port Elizabeth (now known as Nelson Mandela Metropolitan University [NMMU]). The sample for this study comprised six of these students who had all experienced the death of a patient in the clinical learning environment within the previous six months. Furthermore, the students were all English or Afrikaans speaking, as these were the languages understood by the researcher, the participants and the independent coder. This avoided loss of information during the process of interpreting, transcribing and coding of interviews. Four of the participants were Caucasian, one was Black and one was Coloured. All of the participants were 18 years of age or older.

Purposive sampling was used in this study. Yegidis and Weinbach (1996:122) refer to purposive sampling as the selection of participants according to their ability to give the researcher access to some specialised insight or a particular perspective, experience, characteristic or condition that he wishes to understand. Consequently, the researcher approached the second year class lecturer and requested her to explain the proposed research study to the class and to ask for volunteers to participate in the study. The researcher received the names of the volunteers via the lecturer. Those who met the criteria were then approached to participate.

\section{Data collection and analysis}

Data was collected by means of unstructured, individual phenomenological interviews that were recorded using a dictaphone. The researcher posed the following central question to each participant: "How was it for you having to care for a dying or deceased patient?" Interviewing continued until saturation of data was reached, which was evidenced by repeating themes. The interviews were transcribed verbatim. The researcher kept field notes and participants were asked to keep a personal journal for two weeks following the interview. The personal journal of each participant was added to their interview and analysed as a part of the interview.

The interviews and personal journals were analysed according to the descriptive analysis method of Tesch
(1990 in Creswell, 2003:192). Clean sets of transcribed interviews, field notes and participants' personal journals were given to an independent coder experienced in the field of qualitative research. The independent coder was asked to assist with identifying the themes related to student nurses' experiences in accompaniment of the dying patient and caring for the patient after death. On completion, consensus on the identified theme and sub-themes was reached between the researcher and the independent coder. Both agreed that data saturation had been achieved and there was no need for further interviews to be conducted.

\section{Literature control}

The review of literature serves to inform or support the study, especially in conjunction with the collection and analysis of data. The findings from previous studies form the basis for comparison when interpreting the findings from the current study (Brink, 1996:76). In qualitative research, literature should be used inductively meaning that it should not direct the questions asked by the researcher. Related literature was incorporated into the final section of the study, where it was used to compare and contrast with the results that emerged from the study (compare Creswell, 2003:31-33).

\section{Trustworthiness}

According to Agar (1986 in Krefting, 1991:215), a different language is needed to fit the qualitative view of research, namely one that will replace validity and reliability with terms such as credibility, accuracy of representation and authority of the researcher. In order to assess the worth of findings regarding student nurses' experiences of caring for the dying patient, Guba's Model (in Krefting, 1991:215) was utilised to ensure trustworthiness using the four identified aspects, namely truth-value, applicability consistency and neutrality.

\section{Strategies to ensure trustworthiness}

The strategies to ensure trustworthiness were credibility, transferability dependability and confirmability. These are summarised in Table 1.1

\section{Ethical considerations}

The rights of the individual to not be harmed, to give informed consent, to 


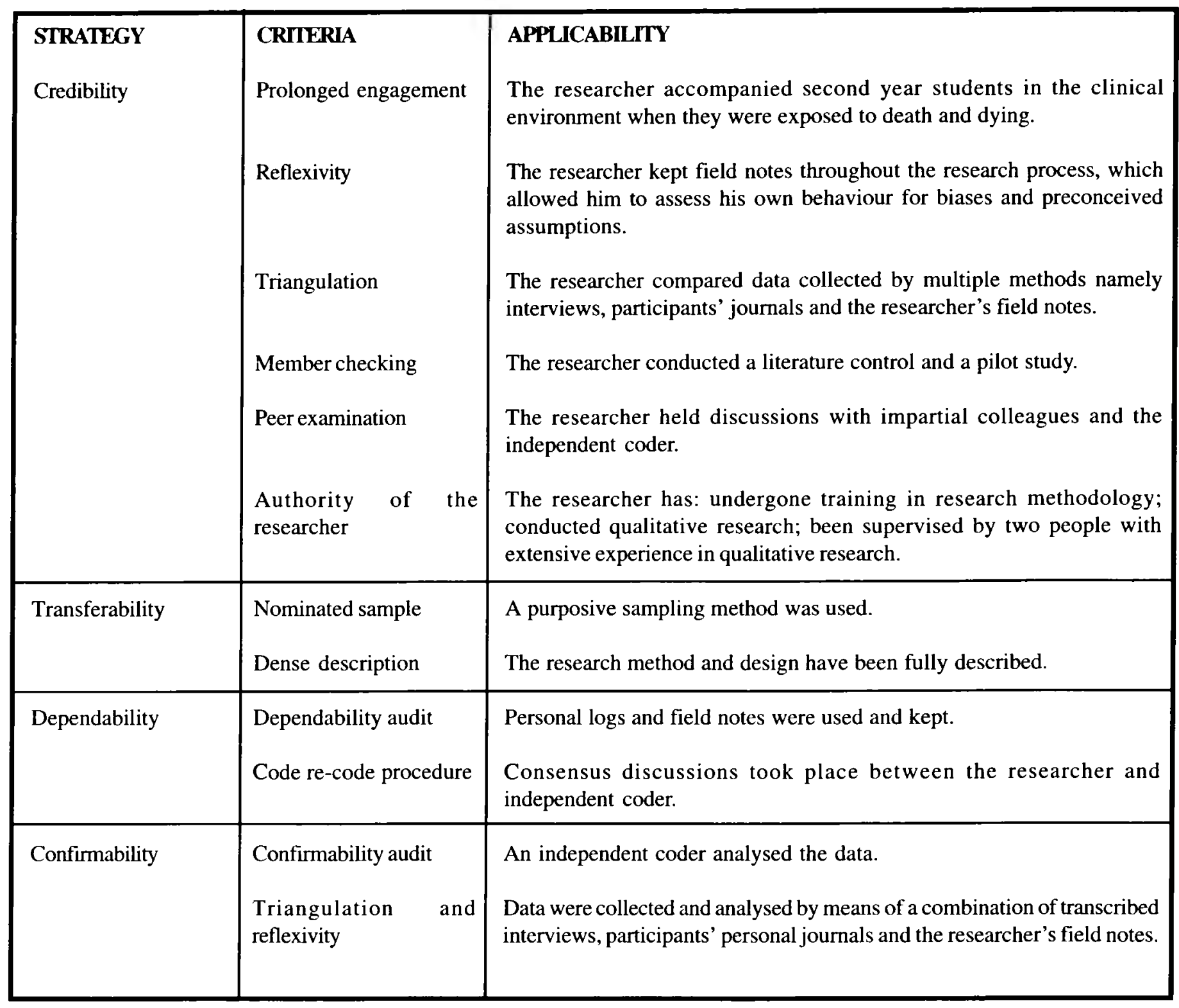

voluntary participation, confidentiality, anonymity and justice (Holloway and Wheeler, 1998:39) were considered throughout the research study. Second year students were invited to participate after being fully informed about the study. The researcher selected participants according to set criteria from the volunteers who submitted their names to him. The researcher conveyed to participants that they were free to withdraw from the study at any time without being penalised. At no time did he engage in deception about the nature of the study (Creswell, 1998:132).

\section{Identified themes/results of the study}

One central theme identified was that In accompaniment of the dying patient, the student nurse experiences turmoil in different relationships - intrapersonal, interpersonal and transcendental. This theme and its sub-themes are identified in Table 1.2.

\section{Discussion of themes}

The participants in this research study described their feelings and experiences related to their accompaniment of dying patients in the clinical learning environment as follows.

\section{Central theme: In their accompaniment of the dying patient, student nurses experienced turmoil in different relationships}

The often young and inexperienced student nurses entering the nursing profession are not fully prepared for the challenges awaiting them in the clinical setting. Some of these challenges, such as caring for dying patients, invoke overwhelming feelings and emotions including shock, frustration, helplessness, self-doubt, anxiety, fear, inadequacy and guilt, as well as feelings of personal loss and grief. Student nurses verbalised how they noted more experienced nurses have become 'immune' to death and do not want to follow suit. Quint (in Loftus, 1998:642) states that it is the first experience of care of the dying that may help to form the nurse's attitudes to further experiences. Time should, therefore, be spent on ensuring that the student is well supported during this period. The subthemes follow:

\section{Sub-Theme 1: Student Nurses} Experienced Intrapersonal Turmoil Due To Feelings And Emotions Invoked By Nursing The Dying Patient

While caring for dying patients, student nurses experienced powerful feelings and emotions such as fear, grief, frustration, anxiety and helplessness. They were 


\begin{tabular}{|c|c|c|}
\hline CENIRAL THEME & SUB-THEMES & SUBSUB-THEMES \\
\hline \multirow[t]{3}{*}{$\begin{array}{l}\text { 1. In their accompani- } \\
\text { ment of the dying } \\
\text { patient, student nurses } \\
\text { experienced turmoil in } \\
\text { different relationships }\end{array}$} & $\begin{array}{l}1.1 \text { Student nurses } \\
\text { experienced intra- } \\
\text { personal turmoil due to } \\
\text { feelings and emotions } \\
\text { invoked by nursing the } \\
\text { dying patient. }\end{array}$ & 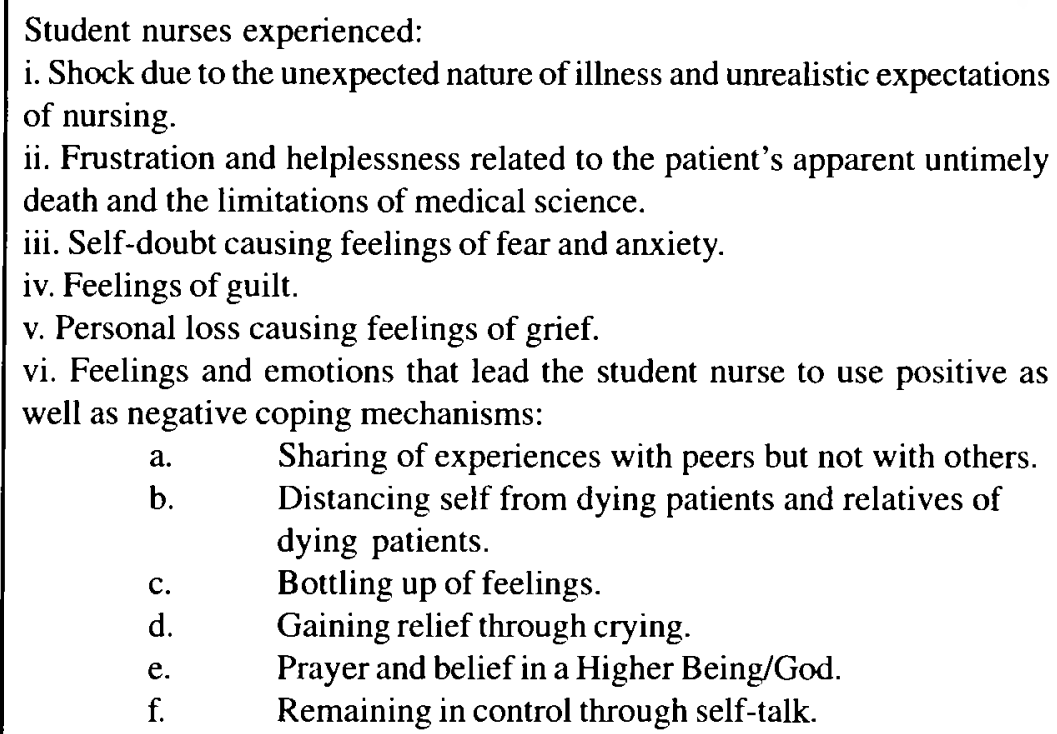 \\
\hline & $\begin{array}{l}1.2 \text { Student nurses } \\
\text { experienced turmoil in } \\
\text { i n t e r p e r s o n a l } \\
\text { relationships due to } \\
\text { conflict resulting from } \\
\text { expectations related to a } \\
\text { role model not being met. }\end{array}$ & $\begin{array}{l}\text { Student nurses experienced: } \\
\text { i. A lack of respect in colleagues for the dead and dying patient. } \\
\text { ii. Insensitivity and indifference toward the patient, leading to neglect of } \\
\text { basic patient care. } \\
\text { iii. Isolation of the dying patient. } \\
\text { iv. A lack of teamwork and the perception that patient care is left up to } \\
\text { student nurses. } \\
\text { v. Anger toward nursing and medical staff. }\end{array}$ \\
\hline & $\begin{array}{l}1.3 \text { Student nurses } \\
\text { experienced a need to find } \\
\text { or create meaning } \\
\text { through a transcendental } \\
\text { relationship. }\end{array}$ & $\begin{array}{l}\text { Student nurses created meaning and gained strength through: } \\
\text { i. Praying for self and the patient. } \\
\text { ii. Own spirituality. } \\
\text { iii. Believing in heaven/a better life after death. }\end{array}$ \\
\hline
\end{tabular}

afraid to provide nursing care to their dying patients, as one student nurse stated, "At first I was afraid of him. It was scary to be in a room with someone dying." As student nurses watched their patients' physical condition worsen, sadness enveloped them. Some felt like withdrawing themselves from the situation because it was so emotionally difficult. The following quote illustrates this: "I began to emotionally distance myself from the family and their needs. I pretended I could not feel their sorrow; however, every time I saw my patient I cried inside." This study revealed that nursing students' death anxiety stemmed from their feelings of personal inadequacy in dealing with these situations, as well as from their limited clinical experience in caring for dying patients (compare Beck, 1997:410-414). to the unexpected nature of illness and unrealistic expectations of nursing

Student nurses may have some preconceived ideas and are not prepared for the reality, as one participant described, "This is what nursing is really. Don't believe that it's floating around the ward giving injections, and you know, handing notes to doctors. You are wrong, very, very wrong. "Carlson, Kotzè and Van Rooyen (2003:35) described how students experience a reality shock due to lack of sufficient orientation and induction to the new learning environment. The impact of this is their realisation that practice in the clinical setting is quite different from what they had expected or even imagined.

\section{Student nurses experienced frustration} and helplessness related to the patient's apparent untimely death and the limitations of medical science

Student nurses became frustrated and found it hard to come to terms with the fact that some patients who died young were good upstanding citizens and people who appeared to have suffered enough in life already. A student stated, "It's mostly people that have maybe had a hard life, but have never done anything seriously wrong like murder anyone or anything. Then these murderers get aw'ay with nothing really going wrong, but then these people who are really, really special and loved and have family, they get terminally ill." The situation of desperately wanting to help someone who is dying, but knowing that there is nothing more that can be done, or not knowing what more one can do, causes the student nurse to have feelings of absolute helplessness. Another student said, "I'd rather die instead of them. I'd do that any day." Virginia Henderson (in Kotzè, 2001:21) describes the nurse as a substitute for what the patient lacks to make him complete, whole or independent, by the loss of physical 
strength, will or cognitive knowledge. She is the dying patient's advocate and when his wishes do not correspond with what she feels is the best care for him, the student nurse suffers from feelings of frustration and helplessness.

\section{Student nurses experienced self-doubt causing feelings of fear and anxiety}

In the hospital environment, death may be seen as a failure. Research, technology and advances in medical science have all failed. Student nurses are anxious and afraid to what degree this failure can be attributed to their lack of knowledge and experience, or some error in their treatment of the patient. As a student nurse verbalised, "When something does happen I will think that I have done something wrong, like I didn't do this well enough, or maybe I could have, I don't know, maybe I'm not qualified enough, or if I had known more. Maybe some other medication could have been tried. " Loftus (1998:645-646) describes how student nurses felt that there was something more that they could have done.

As soon as the nurse begins practical training, she is expected to adapt to death as a visible phenomenon and respond sensitively and effectively in providing care. Student nurses felt that they did not have the ability to care for a dying patient because they were unsure of what to do or how to react to them "Just know'ing that they're dying, and not knowing how to treat them, be cautious with them, or bubbly because now' maybe you're bubbly and full of life, and they don't have much left and don't want to die. How do you deal with that?" A study by Loftus (1998:645) confirms that the fear of making mistakes is what student nurses expressed as causing the highest levels of anxiety in the initial clinical experience on a unit.

\section{Student nurses experienced feelings of guilt}

In this study, student nurses expressed feelings of guilt when a patient had died and felt that they could have done more to help the patient, or that they could possibly have done something wrong or been negligent: "I forgot about his pill. So, I don know, that quite bothered me. I feel bad about it. I mean I just went on lunch maybe I could have said to her (trained nurse), 'Just give me the pills and I'll go give it,' but they don't work that way, they don't let you tell them what to do. You give them the message and that's all. I don't feel responsible because I know I couldn't have done something. but I do feel, thinking maybe he died because of that, but maybe it's not that, maybe he could be alive still." Parkes (1985:497) describes how student nurses experienced intense and usually unrealistic self-blame and guilt when a death occurred after some minor error or discourtesy on their part.

\section{Student nurses experienced personal loss causing feelings of grief}

Nurses, especially students who are responsible for basic nursing care, can spend a great deal of time with patients at a period in their lives when they are most vulnerable. Student nurses verbalised how they experienced grief due to the personal loss felt with the death of a patient. "The longer you spend with a patient, the more attached you get. And then you actually miss them when they're gone". Lees and Ellis (1990:956) explain that, as it is the student nurses who provide the bulk of the hands on patient care, they feel the loss of a friend more than trained staff when the patient dies.

\section{Student nurses experienced feelings and emotions that lead them to use positive as well as negative coping mechanisms}

Student nurses in this study described being able to share experiences with their peers (fellow nursing students, for the most part within their same year group), but preferred not to discuss experiences with others. Lees and Ellis (1990:953) found that student nurses reported to having good friends outside of nursing, of whom the majority were considered supportive, but friends within nursing were the most supportive group.

The student nurses found it easier to cope with death by crying, using selftalk, praying and believing that there is a better place after death. Student nurses revealed that they tended to bottle up their feelings and distance themselves from patients and their colleagues (other nurses, not including peers). The mechanisms they used were:

\section{a) Sharing of experiences with peers, but not with others}

The majority of participants in this study gained their greatest support from each other. "Most of the time it's just my classmates, There is good communication." Onstott (1998:4) established that trained nurses found that talking amongst themselves was useful.

b) Distancing self from dying patients and relatives of dying patients

Student nurses stated that they would treat the dying patient as they should any patient, but would not get too involved. As stated in an interview: "You go in there and you know' that the person is dying, your guard goes up straight away. And then you would not talk to anyone else (patients), just do your job. I'd block myself off. That's my own little way". Student nurses expressed that not becoming attached to the dying patient proved an effective method of being able to care for the dying patient appropriately "without allowing their condition or inevitable death to upset them too much." Onstott (1998:4) found that nurses would rather avoid talking to the family members of a patient who has died.

\section{c) Bottling up of feelings}

There is a general perception amongst student nurses that the more experienced nurses have become 'immune' to death. Student nurses are determined that they do not want to follow suit. " 1 couldn't believe that she was actually a sister caring for people because she is very hard and very insensitive. I never want to become like that, so hard that I don't care if somebody dies. "Kiger (1994:684) found that there is a failure to acknowledge feelings associated with death and dying in the ward and trained staff made it clear that first year students were too junior for their views to have any value. The result was that student nurses developed distancing strategies, worrying at the same time that they might become hard and, as a result, would become unable to nurse with feeling.

\section{d) Gaining relief through crying}

Crying is the most visible way of showing emotion and feelings of grief. Some student nurses prefer not to cry; they would rather avoid situations that could cause them to display such emotion. Other student nurses will permit themselves to continue with their duties, allowing the emotion to build up, and let it out with tears later on in privacy, away from the patients and their relatives. " $l I$ was quiet for the whole day, but when I got home I just cried. I just couldn't keep it inside anymore. Sometimes this thing happens to me in front of the relatives, but I couldn't cry in front of the relatives." Muir (2002:1) says sadness 
relating to the death of a patient is entirely normal and that a nurse should not feel that she is being unprofessional or feel ashamed about crying with family members.

\section{e) Prayer and the belief in a Higher Being/God}

All of the student nurses in this study expressed the use of prayer and their religious beliefs as a major method of coping with the death of a patient and in coping with nursing patients while they are dying. This finding is discussed in more detail under sub-theme 3 .

f) Remaining in control through selftalk

Talking to themselves, giving themselves encouragement or just verbalising their actions out loud, helped to keep the student nurses calm and take their minds off the reality of the immediate situation when managing the dead patient. One student shared "I was talking to myself, but hoping that she could still hear me, just talking away ....I think maybe it was for myself I was doing that, just to calm me down." After an extensive literature search, no data could be found to support the fact that students in other studies made use of self-talk to help them cope when nursing the dead and dying patient.

\section{Sub-Theme 2: Student Nurses Experienced Turmoil In Interpersonal Relationships Due To Conflict Resulting From Expectations Related To a Role Model Not Being Met}

Experienced nursing staff should be the role models for nursing students but the nursing students find that these supposed role models conflict with their idea of what being a nurse is: "They are so-called registered nurses. I feel there are so many sisters who are like that. They don't have the love for it nothing, they're just nursing. I don't know' if they just do it for the money, it can't be because they're not getting that much really, but I don't know why, I feel a sister or a nurse should be someone who really cares for people and really wants to help people." The factors that contribute to students' intrapersonal turmoil are:

- $\quad$ A lack of respect in colleagues for the dead and dying patient: "...you can do all the washes first and then wash the corpse .... I feel that at that time they should still be giving that person a bit of respect."

- Insensitivity and indifference toward the patient leading to neglect of basic patient care: "She was very insensitive; I couldn't believe that she was actually a sister caring for people because she is very hard and insensitive."

- Isolation of the dying patient, because of lack of teamwork and the perception that patient care is left up to student nurses:

"The staff just were not around there. We had to sometimes go there and actually turn her because they just weren't around."

Quinn (1997:182) describes qualified nursing staff as being the key factor influencing the learning environment in hospital placements, with the role of the ward manager being particularly influential. Not only do they have control of the management of the area, but also serve as role models for nursing practice.

\section{Sub-Theme 3: Student Nurses Experienced a Need to Find or Create Meaning through a Transcendental Relationship}

All of the respondents emphasised strongly the value of gaining strength from spiritual beliefs and from being able to pray for a dying patient and believing that they will be in heaven/a better place after they die. One respondent described how she believes that it is essential that one have a set of beliefs in order to cope with caring for the dying patient: "If you don't have religion, you need to find a belief somewhere very quickly ... but you need to believe in something to make it easier, because the moment you don't believe in anything, and someone dies, you believe it's final, that it's such a tragedy, ... a belief still helps you to deal with it." The way in which student nurses created meaning through religious beliefs were praying for themselves and the patient, gaining strength through their own spirituality and believing in heaven/ a better place after death.

\section{As students commented:}

"When I go home I pray for them. Then I'm calm....probably because I can pray for them."

"It's a sort of relief that they've gone to a better place where they are now resting."

Parkes (1985:947) observed that students who had strong religious beliefs, and construed death in these terms, seemed most able to accept the death of patients without undue stress.

\section{Guidelines to optimise accompaniment of student nurses caring for the dying patient in the clinical learning environment}

The guidelines recommended are based on the findings of the research.

Guideline 1: Decreasing and alleviating intrapersonal relationship (relationship with self) turmoil by developing confidence in caring for the dying patient through establishment of supportive relationships.

Guideline 2: Decreasing and alleviating interpersonal relationship turmoil by involving ward staff in the accompaniment of student nurses. The involvement of all personnel in the accompaniment of student nurses will strengthen and instil a sense of ownership in the personnel. Dunn and Hansford (1997:1305) state that participation in student nurse education should be an expected and valued part pf any registered nurse's role. Accompaniment of student nurses by registered nurses in the wards can be accomplished by:

- Continuously reinforcing the critical role of the registered nurse in the teaching and accompaniment of student nurses through consulting and involving them in the organisation of workshops and seminars related to the teaching role of the registered nurse.

- Implementing a nursing personnel development programme where sessions can be presented regarding the basic nursing programme, its objectives, study year outcomes as well as clinical teaching and accompaniment topics with specific reference to the learning and support needs of student nurses at different levels of experience.

- $\quad$ Ensuring effective communication between educators and registered nurses.

- Maintaining regular meetings between the clinical supervisors, lecturers, tutors and registered nurses in order to clarify and solve 
uncertainties regarding student placement, practicals and clinical evaluation.

Having formal, minuted

meetings at least once in each cycle of ward/unit rotation and establishing a resource facility equipped with sufficient media to assist personnel in their development of skills to teach and accompany students while in the clinical learning environment (compare Carlson, 2002:105-106).

Guideline 3: Encouraging a Transcendental Relationship through exploration of the external world and lifeworld. Based on the Nursing Accompaniment Theory of Kotzè (1998:3-14), man learns to know his potential and limitations by the interaction between his body and the world. He experiences his body as inadequate and even as a stumbling block, according to the degree to which he is prevented from exploring his world. The spiritual dimension represents the core of humanness. It is because he has a spiritual dimension that man is aware of himself. Man is an untiring explorer of the world, transcending the body, reaching out to the contents of his external world in an effort to incorporate it into his life-world by exploring and establishing specific relationships. Man is able to transcend himself in his religious practices, creating awareness of norms, a sense of vocation, obedience and willingness to live responsibly and in communication with $\mathrm{God} / \mathrm{a}$ Higher Being.

\section{Limitations of the study}

The following limitations of the study were identified:

- Interviews were conducted with students from a single institution of nursing education - the University of Port Elizabeth. Two of the participants had done practical placements at a private hospital and a state hospital, and four participants had done practical placements at a state hospital only. The study does not include the experiences of students from alternative educational institutions and is limited in exposure to different health care settings such as Hospice.

No male participants agreed to

take part in this study.

\section{Recommendations for}

\section{further research}

The following recommendations, based on findings, for further nursing research are proposed

- Comparison studies of South African nursing students with those in the clinical learning environments of other countries could be conducted in order to establish the effectiveness of different nursing school approaches to the accompaniment of student nurses caring for dying patients.

- A replication of the same study could be done, including a follow-up of the same sample group once they have gained more experience in the clinical learning environment to establish any changes after they have been exposed to more dying patients.

\section{Conclusion}

The researcher ventured into a journey of the lived experiences of student nurses in caring for the dying patient. The entry point was from a position of realising the inadequacies in support in the researcher's own experiences as a student nurse and verbalisations from nursing students following the programme at a later stage, which indicated that their experiences remained similar to those of the researcher. The study produced stories from student nurses indicating that there are definite reasons why student nurses experience turmoil in their various relationships when caring for the dying patient.

\section{References}

ATACK, L; COMACU, M; KENNY, R; LABELLE, N \& MILLER, D 2000: Student and staff relationships in a clinical practice model: Impact on learning. Journal of Nursing Education. 39 (9): 387 392.

BECK, CT 1997: Nursing students' experiences of dying patients. Journal of Nursing Education. 36(9): 408-415.

BLACKWELL SCIENTIFIC PUBLICATIONS 1994: Blackwell's dictionary of nursing. Kenwyn: Juta.
BRINK, H 1996: Fundamentals of research methodology for health care professionals. Kenwyn: Juta.

BURNS, N \& GROVE, SK 1993: The practice of nursing research, conduct, critique utilization. $2^{\text {nd }}$ Edition. Philadelphia: WB Saunders Company.

CANDY, CE 1991: 'Not for resuscitation': The student nurses' viewpoint. Journal of Advanced Nursing. 16: $138-146$.

CARLSON, S 2002: Accompaniment needs of first year nursing students in the clinical learning environment. Unpublished Magister Curationis dissertation: Nelson Mandela Metropolitan University, Port Elizabeth.

CARLSON, S; KOTZÈ, WJ \& VAN ROOYEN, RM 2003: Accompaniment needs of first year nursing students in the clinical learning environment. Curationis. 26(2): 30-39.

CRESWELL, JW 2003: Research design: Qualitative, quantitative, and mixed method approaches. $2^{\text {nd }}$ Edition. Thousand Oaks: Sage

DAVIDSON, P; INTRONA, K; DAL Y, J; PAULL, G; JARVIS, R; ANGUS, J; WILDS, COCKBURN, J; DUNFORD, $M$ \& DRACUP, K 2003: Cardiorespiratory nurses' perceptions of palliative care in non-malignant disease: data for the development of clinical practice. Journal of Critical Care. January. 03/12/2003@23:10. http:// www.findarticles.com/cf_mONUB/1_12/ 96695976/p1/article.jhtml

DELAUNE, SC \& LADNER, PK 2002: Fundamentals of nursing: standards and

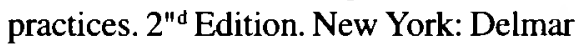
Publishers.

DE VOS, AS (Ed) 1998: Research at grass roots. Pretoria: Van Schaik.

DUNN, SV \& HANSFORD, B 1997: Undergraduate nursing student's perceptions of the clinical learning environment. Journal of Advanced Nursing. 25: 1299-1306.

EARLE, AM; ARGONDIZZO, NT \& KUTSCHER, AH (Eds) 1976: The nurse as caregiver for the terminal patient and his family. New York: Columbia University 
Press Books Ltd.

HECTOR, W \& WHITFIELD 1982:

Nursing care for the dying patient and the family. London: William Heinemann Medical Books Ltd.

HOLLOWAY, I \& WHEELER, S 1998: Qualitative research for nurses. Oxford: Blackwell Science Ltd.

KIGER, AM 1994: Student nurses' involvement with death: The image and the experience. Journal of Advanced Nursing, 20(4): 679-686.

KOTZÉ, WJ 1998: An anthropological nursing science, nursing accompaniment theory. Health SA. 3(2):3-14.

KREFTING, L 1991: Rigor in qualitative research: The assessment of trustworthiness. American Journal of Occupational Therapy. 45(3): 214-222.

LAVERY, M 1993: Death and dying, oh no! Senior Nurse. 13(6): 32-35.

LEES, S \& ELLIS, N 1990: The design of a stress-management programme for nursing personnel. Journal of Advanced Nursing. 15: 946-961

LOFTUS, LA 1998: Student nurses' lived experience of the sudden death of their patients, Journal of Advanced Nursing, 27: 641-648.

LUTHERT, JM \& ROBINSON, L 1993: The Royal Marsden Hospital manual of standards of care. $3^{\text {rd }}$ Edition. Oxford: Blackwell Science Publications.

MUIR, N 2002: Dealing with death: Your first death can leave you shaken and drained, but you need to face up to your emotions before you carry on (student focus). Royal College of Nursing Publishing Company, Oct 2. 03/12/2003 @ 23:48. http://www.findarticles.com/ cf_O/mONWE/3_17/94226141/pl/ article.jhtml

ONSTOTT, AT 1998: Perioperative nursing care when sudden patient death occurs in the OR (operating room). AORN Journal. April.02/12/2003 @ 23:52. http://www.findarticles.com/cf_dls/ mOFSL/n4_v67/20972814/pl/article.jhtml

PARKES, KR 1985: Sressful episodes reported by first-year student nurses: A descriptive account. Social Science
Medicine, 20(9): 945-953.

QUINN, FM 1997: The principles and practice of nurse education. $3^{\text {rd }}$ Edition. Cheltenham: Stanley Thornes (Publishers) Ltd.

UNAIDS 2003: Epidemiology. 02-12-2003 @ 10:47pm. http://www.unaids.org/en/ resources/epidemiology.asp

YEGIDIS, B \& WEINBACH, RW 1996: Research methods for social workers. $2^{\text {nd }}$ Edition. London: Allyn and Bacon.

ZUZILE, M 2003: 53000 people in EC need ARV. The Herald. 1 December: 19. 